\title{
PELATIHAN DAN PENDAMPINGAN PENULISAN KARYA ILMIAH BERBASIS PENELITIAN BAGI GURU MGMP IPA KABUPATEN MEMPAWAH
}

\author{
Mustika Sari $^{1}$, Ivan Eldes Dafrita ${ }^{2}$, Handi Darmawan ${ }^{3}$, Eka Trisianawati ${ }^{4}$, \\ Henny Sulistiany ${ }^{5}$, Nawawi ${ }^{6}$ \\ 1,2,3,4,5,6 Program Studi Pendidikan Biologi, Fakultas Pendidikan MIPA dan Teknologi, \\ IKIP PGRI Pontianak, Jalan Ampera No.88 Pontianak \\ 1e-mail: mustikasari@ikippgriptk.ac.id
}

\begin{abstract}
Abstrak
Pengembangan keprofesian berkelanjutan merupakan salah satu dari unsur utama yang kegiatannya dapat diberikan angka kredit. Masih terdapat kendala yang dialami guru-guru anggota MGMP IPA Kabupaten Mempawah dalam membuat proposal maupun laporan penelitian. Pengabdian kepada Masyarakat ini bertujuan untuk meningkatkan kemampuan guru IPA dalam merencanakan, melaksanakan, melaporkan, serta mempublikasikan hasil penelitian. Metode yang digunakan yaitu pelatihan dan pendampingan bagi guru-guru anggota MGMP IPA Kabupaten Mempawah. Kegiatan pengabdian ini telah dilaksanakan di SMP Negeri 1 Siantan, dimana pada awal kegiatan disampaikan materi mengenai metode, teknik dan evaluasi dalam penulisan karya ilmiah. Tim pengabdian melakukan pendampingan secara berkelompok dan pada akhir kegiatan pengabdian, guru sasaran telah dapat menghasilkan proposal penelitian serta telah memiliki wawasan pengetahuan bagaimana teknik, metode dan cara mempublikasikan karyanya pada jurnal ilmiah.
\end{abstract}

Kata Kunci: Karya ilmiah, Pelatihan dan Pendampingan, MGMP IPA Mempawah

\begin{abstract}
Continuing professional development is one of the main elements in which activities can be given credit values. There are still difficulties experienced by teachers of the MGMP IPA District in Mempawah in making a proposal and research reports. Community Service aims to increase the ability of science teachers to plan, implement, report, and publish research results. The method used is training and mentoring for the MGMP science teachers in Mempawah Regency. This dedicated activity was taken out at SMP Negeri 1 Siantan, wherefrom the beginning of the activity the material was presented regarding methods, techniques, and evaluation in writing scientific papers. The dedicated team provides mentoring in groups and at the end of the dedication activity, the target teacher has been able to produce research proposals and knows how techniques, methods and how to publish their work in scientific journals.
\end{abstract}

Keywords: Research reports, training and mentoring, MGMP IPA Mempawah

\section{PENDAHULUAN}

Menurut Undang-Undang No 14 tahun 2005 tentang guru dan dosen, kompetensi guru meliputi kompetensi pedagogik, kompetensi kepribadian, kompetensi sosial dan kompetensi profesional yang diperoleh melalui pendidikan profesi. Kompetensi pedagogik mewajibkan guru untuk memiliki keterampilan 
dalam merancang pembelajaran sesuai dengan kompetensi yang harus dicapai, termasuk dalam menentukan strategi yang digunakan, media dan materi ajar yang sesuai. Sementara itu pada kompetensi profesional guru dituntut untuk menguasai materi pelajaran secara luas dan mendalam serta dituntut pula untuk mampu mengembangkan materi pembelajaran yang diampu secara kreatif (Aina dkk, 2015). Seorang guru selain mengajar juga dituntut untuk maningkatkan kompetensi profesional dengan melakukan pengembangan diri secara profesional.

Peraturan Bersama Mendiknas dan Kepala BKN Nomor 03/V/PB/2010 Nomor 14 Tahun 2010 tanggal 6 Mei 2010 tentang Petunjuk Pelaksanaan Jabatan Fungsional Guru dan Angka Kreditnya, disebutkan bahwa guru yang akan mengembangkan keprofesian yang berkelanjutan mulai dari kenaikan pangkat jabatan fungsional guru serendah-rendahnya golongan III/b diwajibkan membuat karya inovatif berupa penelitian, karya tulis ilmiah, alat peraga, modul, buku, atau karya teknologi pendidikan yang nilai angka kreditnya disesuaikan. Golongan IV/a ke golongan IV/b harus mempunyai sekurang-kurangnya 1 (satu) laporan hasil penelitian dan 1 (satu) artikel yang dimuat di jurnal yang ber-ISSN (Widayati, 2008).

Karya ilmiah merupakan suatu tulisan yang memuat kajian suatu masalah tertentu dengan menggunakan kaidah-kaidah keilmuan. Kaidah-kaidah keilmuan itu mencakup penggunaan metode ilmiah dan pemenuhan prinsip-prinsip keilmiahan, seperti: objektif, logis, empiris, sistematis, lugas, jelas, dan konsisten. Karya ilmiah dapat dipilah menjadi dua, (i) karya ilmiah yang ditulis dengan berdasar pada hasil penelitian, dan (ii) karya ilmiah yang ditulis dengan berdasar pada hasil pemikiran serius (Sukanti, 2008). Perbedaan Karya Ilmiah dan Karya non-Ilmiah Karya ilmiah adalah karya yang disusun dengan memperhatikan dan menggunakan prinsip-prinsip keilmuan, sedangkan karya nonilmiah adalah karya tulis yang penyusunannya tidak atau kurang memenuhi prinsip-prinsip keilmuan (Sukanti, 2007; Yuberti, 2014). Pengembangan diri seorang guru dapat melalui kegiatan penelitian baik penelitian tindakan kelas (PTK) atau penelitian yang lainnya dan dapat melaporkan hasil penelitian dalam bentuk karya tulis ilmiah serta mempublikasikannya ke dalam jurnal nasional. 
Berdasarkan diskusi dengan beberapa guru dan kepala sekolah di jenjang Pendidikan Menengah Pertama yang tergabung dalam MGMP IPA Kabupaten Mempawah disinyalir guru mengalami kesulitan dalam membuat sebuah artikel ilmiah berdasarkan penelitian. Kegiatan pengabdian dilakukan sebagai bentuk implementasi hasil penelitian yang telah dilakukan (Wahyudi, dkk, 2017). Berdasarkan pemikiran diatas maka tim pengabdian pada masyarakat Program Studi Pendidikan Biologi bermaksud mengadakan kegiatan pelatihan dan pendampingan penulisan karya ilmiah guru berbasis penelitian bagi guru IPA di SMP Negeri 1 Siantan dan MGMP IPA Kabupaten Mempawah. Kegiatan Pengabdian Pada Masyarakat selanjutnya dilaksanakan di SMP Negeri 1 Siantan bekerjasama dengan MGMP IPA Kabupaten Mempawah Kalimantan Barat, dan dilakukan dengan menggunakan metode pelatihan dan pendampingan dari awal program hingga akhir program.

Kegiatan pengabdian yang dilaksanakan di SMP Negeri 1 Siantan dan MGMP IPA Kabupaten Mempawah mampu untuk membantu guru dalam menguasai teknik penulisan artikel ilmiah berbasis penelitian dan memanfaatkannya dalam mengembangkan profesionalitas di sekolah. Kegiatan pengabdian ini bertujuan untuk memberikan pengetahuan kepada guru dalam meningkatkan ketrampilan dalam menyusun penelitian dasar maupun penelitian pengembangan dan memberikan motivasi kepada guru untuk menghasilkan dan mempublikasikan karya ilmiah sebagai upaya untuk meningkatkan profesional guru IPA yang ada di Kabupaten Mempawah.

\section{METODE}

Kegiatan yang dilaksanakan meliputi workshop dan pendampingan menulis karya ilmiah. Pada tahap pertama peserta mendapatkan materi yang berkaitan dengan penulisan karya ilmiah. Selanjutnya, pada tahap kedua, peserta diwajibkan membuat karya ilmiah dengan menggunakan metode pendampingan, partisipatif, serta terbimbing. Tahap ketiga peserta mengumpulkan tugas karya ilmiah dilanjutkan dengan diskusi yang melibatkan semua personalia pengabdian dan peserta pelatihan. 
Tahapan yang dilakukan meliputi: 1) Tahap persiapan pelaksanaan PKM, pada tahapan ini yang dilakukan yaitu; (1) Tim PKM melakukan koordinasi pada MGMP guru IPA Kabupaten Mempawah dan SMP 1 SIANTAN, sosialisasi program PKM pada sekolah mitra, (2) Tim PKM melakukan pertemuan dengan perwakilan guru-guru untuk menentukan materi karya ilmiah yang akan disampaikan dan (3) tim PKM bersama mitra menyusun program pelatihan dan pendampingan. 2) Tahap Pelaksanaan Kegiatan PKM dilaksanakan di SMP Negeri 1 Siantan Kabupaten Mempawah Kalimantan Barat. Adapun langkahlangkah kegiatan yang akan dilakukan dapat dijelaskan sebagai berikut; (1) Peserta akan mengikuti kegiatan workshop penulisan karya ilmiah berbasis penelitian baik penelitian sederhana maupun penelitian pengembangan (R\&D) pada mata pelajaran IPA di SMP Negeri 1 Siantan, (2) Peserta diberikan kesempatan untuk menyusun kerangka penelitian baik penelitian sederhana maupun penelitian pengembangan (R\&D) pada mata pelajaran IPA, (3) Peserta bersama dengan Tim PKM melakukan diskusi terkait karya ilmiah yang akan disusun, (4) Peserta bersama tim melakukan evaluasi kegiatan dan rencana langkah selanjutnya yang akan dilaksanakan.

Tahap Evaluasi dilakukan untuk mengetahui tingkat keberhasilan kegiatan PKM berdasarkan tanggapan peserta setelah mengisi angket kepuasan kegiatan. Indikator kegiatan PKM yang meliputi: (1) Keahlian dan kesiapan fasilitator, (2) Kegunaan materi yang disampaikan, (3) Kesesuaian materi yang disampaikan dengan tema PKM, (3) Kesesuaian pelaksanaan kegiatan dengan harapan peserta, (4) Kesesuaian fasilitas yang diberikan pada saat pelaksanaan kegiatan.

Tanggapan mengenai tiap indikator didalam angket digunakan untuk melihat apakah tiap aspek indikator termasuk kategori tidak baik, kurang baik, baik, atau sangat baik. Secara keseluruhan keberhasilan kegitan PKM yang dilakukan dianalisis dengan langkah-langkah sebagai berikut: (a) Menghitung skor tiap indikator, (b) Menentukan kategorinya dengan ketentuan skor rata-rata yang dapat dilihat pada tabel 1. 
Tabel 1. Kategori Angket Respons Peserta PKM

\begin{tabular}{c|c}
\hline Skor & Kriteria \\
\hline $1,00-1,49$ & kegiatan berjalan dengan tidak baik \\
\hline $1,50-2,49$ & kegiatan berjalan dengan kurang baik \\
\hline $2,50-3,49$ & kegiatan berjalan dengan baik \\
\hline $3,50-4,00$ & kegiatan berjalan dengan sangat baik \\
\hline
\end{tabular}

\section{HASIL DAN PEMBAHASAN}

Secara garis besar kegiatan pengabdian masyarakat ini terbagi dalam dua sesi, yaitu sesi pertama presentasi mengenai teori-teori penulisan karya tulis ilmiah serta pembahasannya. Sesi kedua adalah pendampingan guru dalam praktik penulisan karya tulis ilmiah, dengan contoh penyusunan proposal penelitian, pelaksanaan penelitian serta rancangan laporan hasil penelitian. Peserta berasal dari SMP /MTs yang ada di Kabupaten Mempawah dengan total peserta sebanyak 12 orang guru IPA.

Pada awal kegiatan dilakukan dengan perkenalan, penjelasan tentang kompetensi yang diharapkan, indikator, alokasi waktu dan skenario pelatihan dan pendampingan. Selanjutnya dilakukan eksplorasi pemahaman peserta berkenaan dengan karya ilmiah dan PTK melalui pendekatan andragogi.

Kegiatan dilakukan dengan mengadakan workshop dan pendampingan kepada guru-guru dalam menyusun karya ilmiah berbasis penelitian baik itu pembuatan karya tulis PTK maupun dalam bentuk penelitian eksperimen dan pengembangan dibuka oleh pengawas Sekolah Menengah Pertama (SMP) Kabupten Mempawah dan ketua MGMP IPA Kabupaten Memapawah.

Kegiatan pertama adalah workshop dengan narasumber Handi Darmawan, ST., M.Pd, materi yang diberikan tentang konsep dasar karya ilmiah, prinsipprinsip karya ilmiah, perbedaan karya ilmiah eksperimen dan non eksperimen, PTK dan penelitian pengembangan (Gambar 1). Seminar didahului dengan paparan pendalaman materi karya tulis dilengkapi dengan informasi strategi pembuatan latar belakang, landasan teori, teknik pengumpulan data, analisis data, kaidah dan cara mengakses jurnal ilmiah sebagai referensi dan tempat untuk 
mempublikasikan hasil penelitian. Kegiatan dilaksanakan dengan partisipasi aktif peserta (mitra) dalam bentuk tanya jawab dan diskusi.

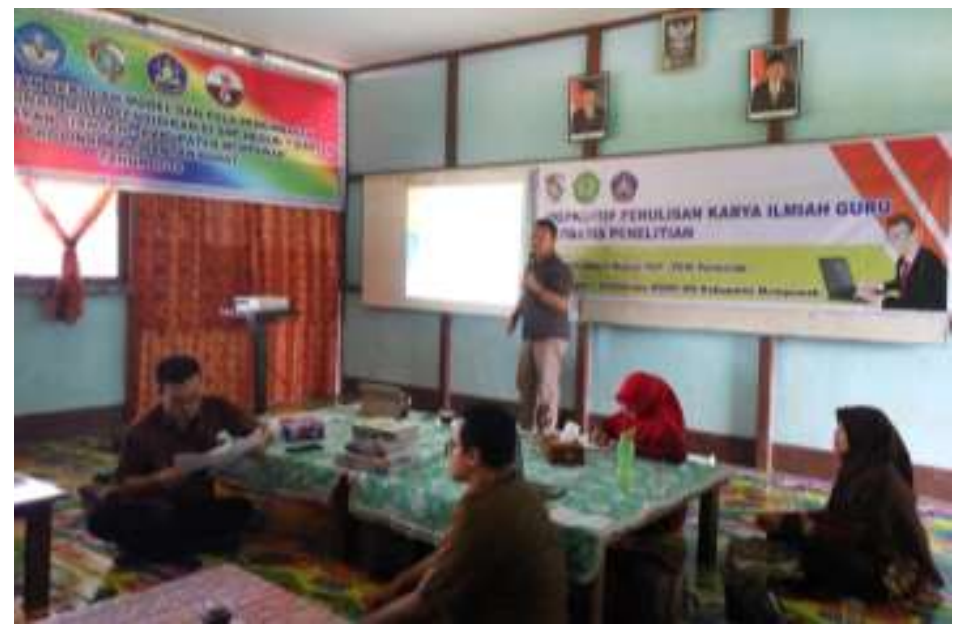

\section{Gambar 1. Penyampaian materi oleh Handi Darmawan, ST., M.Pd}

Pada saat pelaksanaan pengabdian ini, tiap peserta memperhatikan penjelasan narasumber dan beberapa peserta mengajukan pertanyaan pada saat pemaparan tentang materi karya ilmiah dan kerangka menyusun karya ilmiah. Dalam kegiatan workshop tersebut, beberapa guru juga menyampaikan kendala yang dialami saat pengajuan pangkat. Berdasarkan informasi dari beberapa guru tersebut, kendala yang dialami adalah khususnya pada penyusunan proposal PTK. Berdasarkan tanya jawab dengan peserta diperoleh beberapa kelemahan dan kesulitan yang dialami peserta dalam menulis karya ilmiah antara lain: (1) Kesulitan mencari sumber pustaka/rujukan yang sesuai dengan ide penelitian peserta. (2) Dalam menuliskan ide, para pererta masih kurang mampu menyusun kalimat yang efektif. (3) Perumusan masalah masih terlalu luas dan belum mencerminkan pokok masalah yang hendak diteliti. (4) Metode penelitian.

Kegiatan pada sesi pertama ditutup dengan pembagian kelompok untuk pendampingan. Pada sesi ini peserta mempersiapkan penyusunan proposal untuk dikonsultasikan kepada tim pendamping, akan tetapi terdapat kendala yaitu beberapa guru masih belum menemukan ide dan kerangka penelitian, sehingga tim membagi guru dalam beberapa kelompok sesuai dengan tema penelitian untuk mempermudah tim dalam melakukan pendampingan. Tim memberikan arahan tentang tema/ide yang dapat dijadikan sebagai judul penelitian. 
Pada saat sesi pelatihan pembuatan proposal, peserta pelatihan cukup serius meminta masukan dari tim terkait rencana penelitian yang akan dilakukannya. Hal ini mengindikasikan materi yang disampaikan sangat menarik bagi peserta workshop penyusunan proposal dan penelitian. Pemahaman yang diberikan oleh tim pengabdian adalah bagaimana memahami konsep-konsep dasar penyusunan karya ilmiah. Pembahasan konseptual ini dimaksudkan sebagai pemicu pengembangan wawasan peserta, memahami prosedur pelaksanaan penelitian, dan melakukan penelitian untuk meningkatkan kualitas pembelajaran, yang berakibat pada peningkatan kualitas pendidikan.

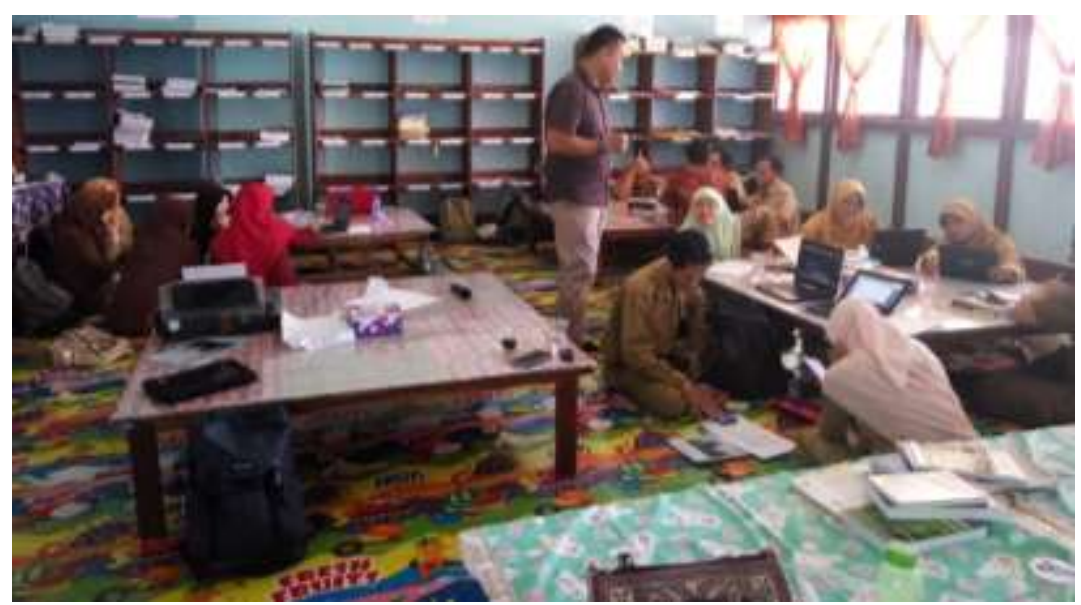

\section{Gambar 2. Kegiatan pendampingan pada masing-masing kelompok}

Setelah para guru mampu menemukan ide maka selanjutnya adalah menyusun proposal penelitian. Tim melakukan pendampingan dan membuka layanan konsultasi bagi para guru dalam merancang proposal dan laporan penelitian. Pendampingan oleh tenaga ahli, dapat memberikan dorongan bagi guru untuk berinovasi, dan sebagai media konsultasi untuk menemukan berbagai alternatif solusi permasalahan dalam penyusunan karya ilmiah. Pendampingan tidak hanya melalui temu tatap muka langsung, namun juga memanfaatkan fasilitas online yang memanfaatkan email maupun aplikasi sosial media yang mendukung dan memungkinkan terjalinnya komunikasi eifisien dan dan efektif. 


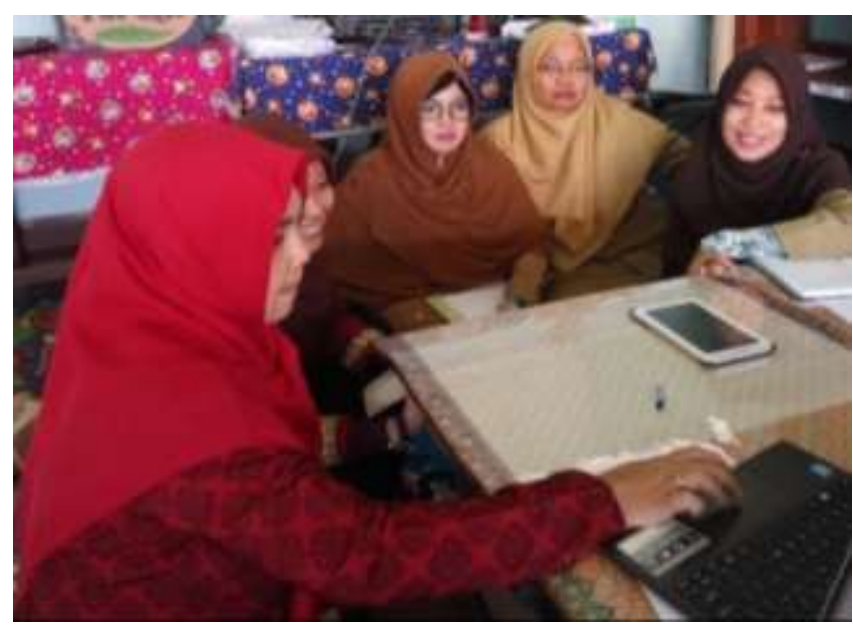

\section{Gambar 3. Kegiatan diskusi kelompok mengenai tema penelitian}

Evaluasi kegiatan menunjukkan bahwa peserta sangat antusias mengikuti kegiatan hal ini dapat dilihat dari indikator pada Tabel 2. Dimana kehadiran dosen-dosen Program Studi Pendidikan Biologi sebagai fasilitator dirasakan sangat membantu peserta. Evalusi kegiatan dilaksanakan dari awal kegiatan sampai pada akhir kegiatan. Untuk merekam pendapat peserta terkait pelaksanaan PKM dari awal sampai akhir, data evaluasi diperoleh menggunakan angket. Hasil analisis angket terdapat pada Tabel 2.

Tabel 2. Hasil analisis angket pelaksanaan kegiatan PKM

\begin{tabular}{clcc}
\hline No & \multicolumn{1}{c}{ Indikator } & Nilai & Kriteria \\
\hline 1 & $\begin{array}{l}\text { Keahlian dan kesiapan narasumber dan } \\
\text { pendamping }\end{array}$ & 3,63 & Sangat Baik \\
\hline 2 & Kebermanfaatan materi yang disampaikan & 3,73 & Sangat Baik \\
\hline 3 & $\begin{array}{l}\text { Kesesuaian materi yang disampaikan dengan } \\
\text { tema PKM }\end{array}$ & 3.64 & Sangat Baik \\
\hline 4 & $\begin{array}{l}\text { Kesesuaian pelaksanaan pelatihan dengan } \\
\text { harapan peserta }\end{array}$ & 3,54 & Sangat Baik \\
\hline 5 & $\begin{array}{l}\text { Bimbingan yang diberikan dosen/instruktur } \\
\text { dalam pelatihan pengabdian pada masyarakar } \\
\text { mudah dimengerti. }\end{array}$ & 3,58 & Sangat Baik \\
\hline 6 & $\begin{array}{l}\text { Perlunya bimbingan berkelanjutan setelah } \\
\text { pelatihan. }\end{array}$ & 3.61 & Sangat Baik \\
\hline
\end{tabular}

Tabel 2 menunjukkan hasil angket evaluasi kegiatan PKM yang dilakukan oleh Tim dari Program Studi Pendidikan Biologi IKIP PGRI Pontianak. Berdasarkan hasil analisis diperoleh bahwa semua indikator yang di lakukan pada 
kegiatan PKM memperoleh kriteria sangat baik. Keahlian dan kesiapan narasumber, materi yang disampaikan telah sesuai dengan apa yang diharapkan oleh peserta. Bimbingan yang diberikan dalam pelatihan juga mudah dimengerti oleh peserta. Berdasarkan hasil secara keseluruhan terdapat beberapa faktor penghambat pada kegiatan ini yaitu: (1) motivasi penelitian yang dilakukan oleh guru, masih rendah, terbukti penelitian yang dilakukan oleh guru-guru MGMP Kabupaten mempawah masih sedikit, (2) waktu pelatihan perlu ditambah sehingga target utama untuk merancang penelitian dan pengembangan penelitian bagi peserta pelatihan belum maksimal. Hal ini dapat dilihat dari angket respon peserta yang menyatakan perlunya bimbingan berkelanjutan setelah pelatihan. Oleh sebab itu kegiatan pelatihan seperti workshop pembuatan proposal penelitian sebaiknya lebih sering dilakukan agar para guru dapat menambah pengetahuan tentang penelitian khususnya.

\section{SIMPULAN}

Kegiatan PKM yang dilakukan oleh tim dosen Program Studi Pendidikan Biologi IKIP PGRI Pontianak telah berjalan dengan baik dan mendapatkan respon yang positif dari peserta. Pelatihan ini dirasakan sangat bermanfaat oleh peserta pelatihan karena dapat menambah pengetahuan dan kemampuan guru-guru IPA dalam medesain proposal penelitian sehingga pada akhirnya nanti dapat meningkatkan kuantitas dan kualitas penelitian guru.

\section{DAFTAR PUSTAKA}

Aina, M., Bambang, H., Retni, S. B., Afreni, H., \& Sadikin, A. (2015). Pelatihan penulisan karya tulis ilmiah bagi guru-guru SMA 8 Kota Jambi. Jurnal pengabdian pada masyarakat, 30 (3): 29-32.

Sukanti, S. (2008). Meningkatkan kompetensi guru melalui pelaksanaan penelitian tindakan kelas. Jurnal Pendidikan Akuntansi Indonesia, 6 (1).

Yuberti, Y. (2014). " Penelitian dan pengembangan" yang belum diminati dan perspektifnya. Jurnal Ilmiah Pendidikan Fisika Al-Biruni, 3 (2): 1-15.

Wahyudi, W., Trisianawati, E., \& Darmawan, H. (2017). Peningkatan keterampilan guru dalam merancang percobaan ipa berbasis pembelajaran inkuiri di kabupaten Bengkayang. GERVASI: Jurnal Pengabdian kepada Masyarakat, 1(1): 61-70. 
Widayati, A. (2008). Penelitian tindakan kelas. Jurnal Pendidikan Akuntansi Indonesia, 6(1).

Wijaya, A. A. (2006). Undang-Undang No 14 tahun 2005 tentang Guru dan Dosen. Semarang: CV Duta Nusaindo 